\title{
DETERMINAN YANG MEMPENGARUHI KEPUTUSAN MEMILIH PROGRAM LINTAS MINAT EKONOMI
}

\author{
Dafrosa Metildis Kortin, Universitas Negeri Makassar \\ dafrosametildiskortin@gmail.com \\ Muhammad Hasan, Universitas Negeri Makassar \\ m.hasan@unm.ac.id \\ Muhammad Dinar, Universitas Negeri Makassar \\ m.dinar5908@unm.ac.id \\ M. Ihsan Said Ahmad, Universitas Negeri Makassar \\ m.ihsansaid@unm.ac.id
}

\begin{abstract}
ABSTRAK
Banyaknya peminat program lintas minat ekonomi di Sekolah Menengah Atas membuktikan bahwa ilmu ekonomi dewasa ini semakin digemari. Hal ini menarik untuk dibahas, untuk mengetahui faktor-faktor yang melatarbelakanginya. Tujuan dari penelitian ini adalah untuk menganalisis pengaruh minat, motivasi, keluarga, guru dan teman sebaya terhadap keputusan siswa jurusan IPA memilih program lintas minat ekonomi di SMA Negeri 4 Makassar. Populasi sekaligus sampel dalam penelitian ini adalah seluruh siswa kelas XI IPA yang memprogram lintas minat ekonomi dengan jumlah 80 orang siswa. Metode pengumpulan data menggunakan kuisioner. Teknik analisis data menggunakan analisis regresi linier berganda dengan bantuan software SPSS Versi 21.0. Hasil penelitian ini menunjukan bahwa variabel minat, motivasi, keluarga, guru dan teman sebaya secara simultan berpengaruh signifikan terhadap keputusan memilih program lintas minat ekonomi. Secara parsial terdapat pengaruh signifikan antara minat, guru dan teman sebaya terhadap keputusan memilih program lintas minat ekonomi. Motivasi dan keluarga tidak berpengaruh secara signifikan terhadap keputusan memilih program lintas minat ekonomi.
\end{abstract}

Kata Kunci: Keputusan Memilih, Lintas Minat, Ekonomi.

\section{ABSTRACT}

Most students interested in cross-major courses economics programs in high schools proves that economics is increasingly popular nowadays. This is interesting to discuss, to find out the factors behind it. The purpose of this study was to analyze the influence of interest, motivation, family, teachers and peers on the decision of students majoring in natural sciences to choose a cross-major courses economics program in SMA Negeri 4 Makassar. The population, as well as the sample in this study, were all students of class XI IPA who programmed cross-major courses economic interests with a total of 80 students. The data collection method uses a questionnaire. Data analysis techniques used multiple linear regression analysis with the help of SPSS Version 21.0 software. The 
results of this study indicate that the variables of interest, motivation, family, teachers and peers simultaneously have a significant effect on the decision to choose a cross-major courses economics program. Partially there is a significant influence between interests, teachers and peers on the decision to choose an economics cross-major courses program. Motivation and family do not significantly influence the decision to choose a cross-interest economics program.

Keywords: Decision to Choose, Cross-major courses, Economics.

\section{PENDAHULUAN}

Pendidikan pada dasarnya tidak dapat dipisahkan dari kehidupan manusia. Saat ini para pendidik beserta peserta didik mendapatkan tantangan baru mengenai perubahan penggunaan kurikulum dari Kurikulum Tingkat Satuan Pendidikan (KTSP 2006) menuju Kurikulum 2013. Sekolah Menengah Atas (SMA) merupakan jenjang pendidikan formal di Indonesia yang bertujuan untuk memberikan bekal ilmu pada siswa yang akan melanjutkan ke Perguruan Tinggi. Program lintas minat pada kurikulum 2013 ini merupakan program baru dan kebijakan baru dari pemerintah. Program ini bertujuan untuk memberikan kesempatan dan peluang kepada siswa untuk dapat memilih dan mempelajari mata pelajaran yang tidak ada pada program peminatan. Kajian tentang program peminatan dalam pendidikan menengah, perferensi siswa dalam memilih program peminatan dan dampaknya terhadap proses pembelajaran telah dilakukan, khususnya yang terkait dengan pemiliham program spesialisasi (Guyon et al., 2012; Dustmann et al., 2016). Sesuai dengan bidang ilmunya, program peminatan ekonomi menawarkan berbagai ilmu pengetahuan yang berhubungan dengan ekonomi. Melalui program peminatan ekonomi, siswa kelas IPA dikenalkan dan diajarkan pelajaran yang berhubungan dengan ekonomi yang tidak diajarkan di kelas IPA.

Pemilihan program peminatan ekonomi terkait dengan pilihan karir dan keputusan dalam melanjutkan Pendidikan tinggi siswa pada masa yang akan datang. Pengambilan keputusan dalam memilih program lintas minat menarik minat banyak peneliti pendidikan karena ini adalah bagian yang sangat penting dalam perencanaan bimbingan karir untuk siswa, alokasi anggaran untuk berbagai lembaga yang menyediakan pelatihan untuk jalur karir, dan pengembangan kurikulum. Pop'Eleches \& Urquiola (2013) mengusulkan dan menguji model dengan memasukkan faktor peran orang tua, efikasi diri, dan peran teman sebaya, sedangkan Pascual (2014), memasukkan faktor ketersediaan pekerjaan pada masa yang akan datang sebagai faktor utama dalam memilih program lintas minat. Lebih lanjut lagi, Koech et al., (2016) menyimpulkan bahwa interaksi sosial siswa dengan guru, orang tua, dan teman sebaya merupakan faktor penentu dalam pemilihan lintas minat. Selain itu, Abarro (2016) menemukan bahwa jenis kelamin, pendapatan bulanan rata-rata kepala rumah tangga, preferensi sekolah, pekerjaan kepala rumah tangga, dan peringkat skolastik rata-rata terkait dengan pilihan karir siswa Kelas 9 merupakan faktor penentu dalam pemilihan program lintas minat.

Sehubungan dengan faktor-faktor yang menentukan keputusan dalam memilih program lintas minat tersebut, peneliti berhasil mengidentifikasi 
berbagai faktor yang mempengaruhi peserta didik memutuskan untuk memilih program lintas minat ekonomi yang meliputi adanya minat, motivasi, dukungan dari keluarga, guru, dan pengaruh teman sebaya. Dalam pemilihan program lintas minat, minat merupakan salah satu faktor yang berpengaruh terhadap pemilihan jurusan. Minat berasal dari dalam setiap individu itu sendiri yang merupakan kesadaran seseorang terhadap suatu objek, suatu masalah atau situasi yang mengandung kaitannya dengan dirinya (Suriyani, 2016). Motivasi memiliki peran yang penting dalam melakukan keputusan pemilihan, karena dengan adanya motivasi dari dalam diri maka siswa akan terdorong untuk melakukan pemilihan (Puspitasari \& Patrikha, 2018). Dukungan dari keluarga juga sangat mempengaruhi dalam keputusan pemilihan yang dilakukan oleh peserta didik karena keluarga memberikan dorongan disetiap salah satu keluarganya akan melakukan keputusan terutama keputusan pemilihan yang berkaitan dengan pendidikannya. Keluarga juga berperan secara aktif dalam memberikan dukungan bagi anggota keluarga lainnya, karena dukungan keluarga yang diberikan ini dapat mempengaruhi bagaimana seorang individu menjalani kehidupannya (Istifarani, 2016).

Faktor lain yang turut berpengaruh terhadap keputusan pemilihan program lintas minat yaitu faktor guru dan faktor teman sebaya. Guru harus menjadi teladan bagi peserta didik dengan sikap dan perilaku yang dimiliki. Woolfolk (2009) menyatakan bahwa siswa akan lebih termotivasi dalam belajar ketika mereka memiliki guru yang perhatian dan memiliki hubungan baik, bertanggung jawab dan tegas, dan kreatif serta inovatif. Hubungan guru dan siswa akan berpengaruh terhadap peserta didik entah itu baik atau tidak baik. Siswa yang mempunyai hubungan tidak baik dengan gurunya mengakibatkan kurangnya minat untuk mengikuti pembelajaran sedangkan siswa yang mempunyai hubungan baik dengan guru salah satu mata pelajaran dalam hal ini mata pelajaran ekonomi akan mendorong peserta didik tersebut ingin selalu diajar oleh guru tersebut. Faktor teman sebaya dalam setiap keputusan memang memberikan pengaruh, baik secara langsung maupun tidak secara langsung. Lingkungan teman sebaya merupakan suatu interaksi yang intensif dan cukup teratur dengan orang-orang yang mempunyai kesamaan dalam usia dan status interaksi tersebut berupa interaksi dengan teman sebaya dilingkungan sekolah maupun di lingkungan tempat tinggal. Dukungan teman sebaya diduga menjadi salah satu faktor penting yang dapat mempengaruhi kematangan karier. Terlebih pada masa ini remaja lebih banyak menghabiskan waktunya dengan teman sebaya dibanding keluarganya. Intensitas dan waktu yang dihabiskan bersama teman lebih besar pada masa remaja dibandingkan waktu lain dalam rentang kehidupan (Papalia et al., 2009).

Pengambilan keputusan adalah proses penentuan tindakan yang akan dilakukan untuk memecahkan masalah dalam rangkaian kegiatan untuk mencapai tujuan. Pembuatan keputusan dapat didefinisikan sebagai penentuan serangkaian kegiatan untuk mencapai hasil yang diinginkan (Handoko, 2011), artinya dalam menentukan sebuah keputusan seseorang akan menetapkan beberapa kegiatan yang akan dilakukan untuk mencapai tujuan. Hakikat pengambilan keputusan adalah memilih dua alternatif atau lebih untuk melakukan suatu tindakan tertentu baik secara pribadi maupun kelompok (Syafaruddin \& Anzizhan, 2014). 
Berdasarkan penelusuran data pendahuluan di SMA Negeri 4 Makassar diperoleh data bahwa peminat program lintas minat ekonomi mengalami peningkatan dari tahun ke tahun yang ditandai dengan banyaknya siswa yang mengambil program lintas minat tersebut. Agar program ini memiliki kualitas maka dibutuhkan siswa siswa yang memiliki ketertarikan dan kemampuan di bidang ini, sehingga siswa tidak hanya sekedar untuk memilih saja. Hal ini menjadi salah satu hal yang penting untuk mengetahui faktor-faktor yang melatarbelakangi siswa jurusan IPA memilih lintas minat ekonomi untuk dipelajarinya.

Kajian ini berkontribusi pada literatur tentang pemilihan lintas minat ekonomi sebagai sebuah proses kognitif. Kajian tentang faktor-faktor yang mempengaruhi pemilihan lintas minat telah banyak dikaji oleh para ahli dengan menggunakan basis Social Cognitive Career Theory (SSCT) (Lent et al., 1994) sebagai kerangka teori untuk penyelidikan empiris (Rottinghaus et al., 2018). Beberapa penelitian terdahulu secara empiris telah menunjukkan bahwa keyakinan diri (Patrick et al., 2011; Mau \& Li, 2018), minat (Toker \& Ackerman, 2012), keterlibatan sekolah (Miller et al., 2018), kemampuan akademik, dan latar belakang keluarga (NCES, 2015) merupakan faktor-faktor yang berkaitan dengan keputusan memilih lintas minat.

Kajian ini bertujuan untuk membuktikan pengaruh minat, motivasi, keluarga, guru dan teman sebaya terhadap keputusan memilih program lintas minat ekonomi di SMA Negeri 4 Makassar. Berbeda dengan kajiankajian sebelumnya, kajian penelitian ini memasukkan variabel guru dan teman sebaya untuk dikaji berdasarkan Social Cognitive Career Theory (SSCT). Lent et al., (1994) mengembangkan SCCT untuk memfasilitasi pemahaman tentang pilihan karir, minat, dan proses kinerja. Teori ini mengidentifikasi faktor-faktor yang saling mempengaruhi ketika seorang siswa memilih jalur tertentu dan berkembang di jalur karier yang dipilih. Selain itu, teori ini juga menyediakan kerangka kerja tentang menggunakan proses kognitif sosial untuk menjelaskan keberhasilan dan kegagalan, hasil akademik, dan hasil karir. SCCT dibagi menjadi dua tingkat analisis teoretis, yang penyajian variabel kognitif dan analisis set variabel tambahan yang dapat memengaruhi minat terkait karier dan perilaku pilihan (Lent et al., 1994).

Tingkat pertama mencakup variabel inti yang memengaruhi keputusan memilih yang meliputi: efikasi diri, harapan hasil, dan tujuan. Efikasi diri melibatkan persepsi siswa apakah ia dapat berhasil pada pilihan tertentu. Harapan hasil termasuk penghargaan nyata yang dirasakan siswa untuk kinerja yang sukses. Tujuan, menurut Bandura (1989), adalah tekad siswa untuk mencapai hasil tertentu. Di sisi lain, level kedua mencakup input pribadi, pengalaman belajar, dan pengaruh kontekstual. Input pribadi terdiri dari atribut fisik siswa. Faktor kontekstual mempertimbangkan kondisi lingkungan yang berbeda, sehingga berdasarkan fakta teoritis dan fakta empirik tersebut, maka dalam penelitian ini akan dikaji pengaruh minat, motivasi, keluarga, guru dan teman sebaya terhadap keputusan memilih program lintas minat ekonomi di SMA Negeri 4 Makassar. 


\section{METODE PENELITIAN}

Penelitian ini menggunakan jenis penelitian kuantitatif dengan mengajukan beberapa pernyataan dalam bentuk kuesioner yang dibagikan kepada responden yaitu siswa kelas XI IPA SMA Negeri 4 Makassar. Populasi dalam penelitian ini adalah seluruh siswa kelas XI IPA SMA Negeri 4 Makassar yang memprogram lintas minat ekonomi sebanyak 80 orang. Pengambilan sampel dengan mengambil jumlah keseluruhan dari populasi sehingga penelitiannya merupakan penelitian populasi. Variabel bebas dalam penelitian ini adalah minat, motivasi, keluarga, guru dan teman sebaya, sedangkan variabel terikat dalam penelitian ini adalah keputusan memilih program lintas minat ekonomi. Deskripsi variabel, sub variabel, dan indikator yang digunakan dalam penelitian dapat dilihat pada Tabel 1.

Tabel 1. Variabel, Sub Variabel, dan Indikator Penelitian

\begin{tabular}{|c|c|c|c|}
\hline No & Variabel & Sub Variabel & Indikator \\
\hline 1. & Minat & $\begin{array}{l}\text { 1. Perasaan senang } \\
\text { 2. Ketertarikan } \\
\text { siswa } \\
\text { 3. Perhatian siswa }\end{array}$ & $\begin{array}{l}\text { 1. Senang dalam mengikuti } \\
\text { pembelajaran } \\
\text { 2. Aktif dalam kegiatan } \\
\text { pembelajaran } \\
\text { 3. Konsentrasi saat belajar }\end{array}$ \\
\hline 2. & Motivasi & $\begin{array}{l}\text { 1. Keinginan } \\
\text { 2. Dorongan } \\
\text { 3. Cita-cita }\end{array}$ & $\begin{array}{l}\text { 1. Adanya orientasi masa depan } \\
\text { 2. Usaha belajar yang lebih baik } \\
\text { 3. Usaha yang sungguh-sungguh }\end{array}$ \\
\hline 3. & Keluarga & $\begin{array}{l}\text { 1. Cara orang tua } \\
\text { mendidik } \\
\text { 2. Relasi antar } \\
\text { anggota keluarga } \\
\text { 3. Keadaan } \\
\text { ekonomi } \\
\text { keluarga }\end{array}$ & $\begin{array}{l}\text { 1. Memperhatikan pendidikan } \\
\text { anak } \\
\text { 2. Dekat dengan semua anggota } \\
\text { keluarga } \\
\text { 3. Fasilitas belajar terpenuhi }\end{array}$ \\
\hline 4. & Guru & $\begin{array}{l}\text { 1. Pengetahuan } \\
\text { 2. Keterampilan } \\
\text { 3. Metode } \\
\text { pembelajaran }\end{array}$ & $\begin{array}{l}\text { 1. Menguasi materi pembelajaran } \\
\text { 2. Relasi dengan siswa } \\
\text { 3. Menguasi metode pembelajaran } \\
\text { yang diterapkan }\end{array}$ \\
\hline 5. & $\begin{array}{l}\text { Teman } \\
\text { sebaya }\end{array}$ & $\begin{array}{l}\text { 1. Kerja sama } \\
\text { 2. Persaingan } \\
\text { 3. Pertentangan }\end{array}$ & $\begin{array}{l}\text { 1. Interaksi antar siswa } \\
\text { 2. Berkompetisi untuk menjadi } \\
\text { yang terbaik } \\
\text { 3. Adanya perbedaan pendapat }\end{array}$ \\
\hline 6. & $\begin{array}{l}\text { Keputusan } \\
\text { memilih }\end{array}$ & $\begin{array}{l}\text { 1. Kemampuan } \\
\text { 2. Kemauan } \\
\text { 3. Tantangan }\end{array}$ & $\begin{array}{l}\text { 1. Mudah dipahami } \\
\text { 2. Bukan karena paksaan } \\
\text { 3. Merasa tertantang }\end{array}$ \\
\hline
\end{tabular}

Teknik pengumpulan data yang digunakan dalam penelitian ini adalah kuesioner. Instrumen dalam penelitian ini menggunakan kuesioner dengan skala likert yang digunakan untuk mengukur minat, motivasi, keluarga, guru dan teman sebaya. Penetapan skor diberikan kepada jawaban setiap responden dengan nilai 1 sampai 5 dengan asumsi jawaban (1) sangat tidak setuju, (2) 
tidak setuju, (3) ragu-ragu, (4) setuju, dan (5) sangat setuju. Pengujian instrumen yang digunakan dalam penelitian ini adalah uji validitas dan uji reliabilitas. Teknik analisis data yang digunakan dalam penelitian ini adalah uji statistik deskriptif, dan uji asumsi klasik. Teknik analisis data yang digunakan adalah analisis regresi berganda dan pengujian hipotesis dengan uji $t$ dan uji F. Pengolahan data akan menggunakan software SPPS Versi 21.0.

\section{HASIL PENELITIAN DAN PEMBAHASAN}

Pengujian validitas yang digunakan dalam penelitian ini berupa pengujian validitas isi (content validity) yang mengukur sejauh mana kuesioner tersebut mewakili semua aspek yang dianggap sebagai kerangka konsep. Pengujian validitas ini dilakukan dengan menghitung korelasi antara skor butir instrumen dengan skor total. Nilai koefisien korelasi antara skor setiap item dengan skor total dihitung dengan korelasi product moment (product moment pearson correlation), suatu instrument dinyatakan valid apabila koefisien $r$ hitung lebih besar dibandingkan koefisien korelasi $r$ tabel pada taraf signifikan 5\% (Gujarati \& Dawn, 2009; Munarfah \& Hasan, 2019). Hasilnya menunjukkan bahwa koefisien $r$ hitung dari setiap item lebih besar dibandingan $\mathrm{r}$ tabel pada taraf signifikan 5\%, sehingga dapat dikatakan masing masing indikator setiap variabel adalah valid.

Dasar pengambilan keputusan uji reliabilitas dalam penelitian ini adalah jika nilai Cronbach's Alpha $>0,60$, maka kuesioner dinyatakan reliabel, sementara jika nilai Cronbach's Alpha $<0,60$ maka kuesioner dinyatakan tidak reliabel (Gujarati \& Dawn, 2009; Munarfah \& Hasan, 2019). Hasil pengujian reliabilitas dapat dilihat pada Tabel 2.

Tabel 2. Uji Reliabilitas

\begin{tabular}{clcc}
\hline No. & \multicolumn{1}{c}{ Variabel } & Cronbach's Alpha & Keterangan \\
\hline 1. & Minat & 0,968 & Reliabel \\
2. & Motivasi & 0,539 & Reliabel \\
3. & Keluarga & 0,660 & Reliabel \\
4. & Guru & 0,635 & Reliabel \\
5. & Teman sebaya & 0,238 & Reliabel \\
6. & Keputusan & 0,764 & Reliabel \\
& Memilih & & \\
\hline
\end{tabular}

Hasil uji reliabilitas menunjukkan untuk variabel minat memiliki nilai sebesar 0,729 ; variabel motivasi memiliki nilai 0,704 ; variabel keluarga memiliki nilai 0,736 ; variabel guru memiliki nilai 0,729 ; variabel teman sebaya memiliki nilai 0,694; dan variabel keputusan memilih memiliki nilai 0,764. Sehingga dapat disimpulkan bahwa seluruh butir pertanyaan dalam variabelvariabel tersebut reliabel, karena seruluh variabel mempunyai nilai Cronbach's Alpha $>0,60$. 
Uji asumsi klasik merupakan persyaratan statistik yang harus dipenuhi pada analisis regresi linear berganda yang berbasis ordinary least square $(O L S)$. Uji asumsi klasik yang digunakan dalam penelitian ini meliputi uji linearitas, uji multikolinearitas, dan uji heteroskedastisitas. Hasil pengujian linearitas dapat dilihat pada Tabel 3.

Tabel 3. Uji Linearitas

\begin{tabular}{clcc}
\hline No. & Variabel & Deviation from Linearity & Keterangan \\
\hline 1. & Minat & 0,968 & Hubungan linear \\
2. & Motivasi & 0,539 & Hubungan linear \\
3. & Keluarga & 0,660 & Hubungan linear \\
4. & Guru & 0,635 & Hubungan linear \\
5. & Teman sebaya & 0,238 & Hubungan linear \\
\hline
\end{tabular}

Variabel dikatakan mempunyai hubungan linier apabila signifikansi lebih besar dari 0,05 (Gujarati \& Dawn, 2009; Munarfah \& Hasan, 2019). Dari hasil uji linearitas variabel minat, motivasi, keluarga, guru dan teman sebaya memperoleh nilai deviation from linearity lebih besar dari 0,05 sehingga dapat disimpulkan adanya hubungan yang linear. Hasil pengujian multikolinearitas dapat dilihat pada Tabel 4.

Tabel 4. Uji Multikolonieritas

\begin{tabular}{clccl}
\hline No. & Variabel & Tolerance & VIF & Keterangan \\
\hline 1. & Minat & 0,844 & 1,185 & Tidak terjadi multikolinearitas \\
2. & Motivasi & 0,715 & 1,399 & Tidak terjadi multikolinearitas \\
3. & Keluarga & 0,642 & 1,558 & Tidak terjadi multikolinearitas \\
4. & Guru & 0,643 & 1,555 & Tidak terjadi multikolinearitas \\
5. & Teman sebaya & 0,896 & 1,116 & Tidak terjadi multikolinearitas \\
\hline
\end{tabular}

Untuk mendeteksi multikolinearitas di dalam model regresi adalah dengan melihat nilai tolerance dan VIF. Apabila tolerance $>0,10$ dan VIF $<10$ (Gujarati \& Dawn, 2009; Munarfah \& Hasan, 2019). Dari hasil uji multikolinearitas semua variabel bebas mempunyai nilai tolerance $>0,10$ dan VIF $<10$, sehingga dapat disimpulkan tidak terjadi multikolinearitas.

Terjadinya heterokedastisitas ditunjukkan apabila nilai signifikan variabel bebas < 0,05 (Gujarati \& Dawn, 2009; Munarfah \& Hasan, 2019). Berdasarkan hasil uji glejser menunjukkan bahwa variabel minat, motivasi, keluarga, guru dan teman sebaya tidak terjadi heterokedastisitas karena nilai signifikan lebih besar dari 0,05 .

Tujuan dari kajian ini adalah untuk mengetahui pengaruh minat, motivasi, keluarga, guru dan teman sebaya terhadap keputusan memilih program lintas minat ekonomi di SMA Negeri 4 Makassar. Ringkasan hasil analisis regresi linier berganda dan pengujian hipotesis melalui software SPSS Versi 21.0 dapat dilihat pada Tabel 5.

Berdasarkan hasil analisis regresi linier berganda melalui software SPSS Versi 21.0 diperoleh persamaan regresi sebagai berikut:

$$
\mathrm{Y}=2,158+0,353(\mathrm{X} 1)+0,147(\mathrm{X} 2)+0,084(\mathrm{X} 3)+0,459(\mathrm{X} 4)+0,276(\mathrm{X} 5)
$$


Besarnya kontribusi variabel minat, motivasi, keluarga, guru dan teman sebaya terhadap keputusan memilih program lintas minat ekonomi diketahui dari nilai koefisien determinasi sebesar 0,419 atau 41,9\%. Ini berarti bahwa $41,9 \%$ variabel keputusan memilih lintas minat ekonomi dijelaskan oleh variabel minat, motivasi, keluarga, guru dan teman sebaya, sedangkan sisanya 58,1\% dijelaskan oleh faktor-faktor lain yang tidak terdapat di dalam model penelitian.

Tabel 5. Hasil Uji Regresi Berganda

\begin{tabular}{lccccc}
\hline \multicolumn{1}{c}{ Variabel } & B & $\begin{array}{c}\text { Standar } \\
\text { Kesalahan }\end{array}$ & Beta & t & Sig. \\
\hline (Constant) & -2.158 & 5.797 & & -0.372 & 0.711 \\
Minat & 0.353 & 0.082 & 0.416 & 4.313 & 0.000 \\
Motivasi & -0.147 & 0.097 & -0.159 & -1.515 & 0.134 \\
Keluarga & -0.084 & 0.101 & -0.093 & -0.838 & 0.404 \\
Guru & 0.459 & 0.130 & 0.391 & 3.539 & 0.001 \\
Teman sebaya & 0.276 & 0.100 & 0.257 & 2.742 & 0.008 \\
r: 0.648 & & & & & \\
$\mathrm{r}^{2}: 0.419$ & & & & & \\
F : 10.686, sig. 0,000 & & & & & \\
\hline
\end{tabular}

Berdasarkan hasil pengolahan data menunjukan bahwa nilai $\mathrm{F}$ sebesar 10,686 dengan sig. $=0,000<0,05$ yang berarti bahwa variabel minat, motivasi, keluarga, guru dan teman sebaya secara simultan berpengaruh signifikan terhadap keputusan memilih program lintas minat ekonomi di SMA Negeri 4 Makassar. Berdasarkan hasil uji t menunjukan bahwa variabel minat, guru, dan teman sebaya secara parsial mempunyai pengaruh yang signifikan terhadap keputusan memilih program lintas minat ekonomi di SMA Negeri 4 Makassar, sedangkan variabel motivasi dan keluarga secara parsial mempunyai pengaruh yang tidak signifikan terhadap keputusan memilih program lintas minat ekonomi di SMA Negeri 4 Makassar.

Berdasarkan hasil penelitian menunjukkan bahwa minat berpengaruh signifikan terhadap keputusan memilih program lintas minat ekonomi, sehingga dapat dikatakan bahwa siswa memilih program lintas minat ekonomi karena adanya ketertarikan pada program tersebut, yang ditunjukan dengan siswa lebih memilih program lintas minat ekonomi dibandingkan dengan program lintas minat yang lain. Hasil penelitian ini sejalan dengan temuan Rufaidah (2015) yang menjelaskan bahwa adanya pengaruh yang signifikan antara minat dengan putusan memilih jurusan. Jelas bahwa faktor minat merupakan variabel yang menentukan dalam keputusan untuk memilih program lintas minat ekonomi.

Temuan lain penelitian ini menunjukkan bahwa motivasi berpengaruh tidak signifikan terhadap keputusan memilih program lintas minat ekonomi. Hal ini dikarenakan masih kurangnya kesadaran siswa untuk belajar serta adanya pemberian motivasi yang kurang tepat, baik dari lingkungan internal maupun lingkungan eksternal siswa. Hasil penelitian ini berbeda dengan 
temuan Afriska (2015) yang menemukan bahwa faktor motivasi berpengaruh terhadap keputusan memilih program lintas minat eknomi.

Sejalan dengan variabel motivasi, faktor keluarga juga berpengaruh tidak signifikan terhadap keputusan memilih program lintas minat ekonomi. Hal ini dikarenakan kurangnya relasi antara siswa dengan anggota keluarganya berupa tidak adanya sifat keterbukaan, karena pada dasarnya seorang siswa masih membutuhkan nasehat untuk membantu mereka dalam mengambil suatu keputusan. Hasil penelitian ini berbeda dengan temuan Devianti (2015) yang menemukan bahwa dukungan orang tua secara umum berkontribusi secara signifikan terhadap minat siswa pada jurusan yang ditempati.

Temuan penelitian ini juga menunjukan bahwa faktor guru berpengaruh signifikan terhadap keputusan memilih program lintas minat ekonomi. Jadi dapat dikatakan bahwa faktor guru menjadi salah satu alasan siswa memilih program lintas minat ekonomi. Adanya hubungan yang baik dengan guru mata pelajaran ekonomi mendorong siswa untuk selalu diajar oleh guru. Hasil penelitian ini sejalan dengan temuan Istiqomah (2017) yang menemukan bahwa faktor lingkungan sekolah yang meliputi fasilitas, guru, dan teman sebaya pada kategori "tinggi" atau sangat berpengaruh pada minat siswa untuk memilih mata pelajaran.

Sejalan dengan faktor guru, faktor teman sebaya juga berpengaruh signifikan terhadap keputusan memilih program lintas minat ekonomi. Jadi dapat dikatakan bahwa faktor teman sebaya menjadi salah satu faktor yang mempengaruhi siswa memilih program lintas minat ekonomi. Dalam menentukan sebuah keputusan seorang siswa cenderung mengikuti seseorang yang mereka anggap teman. Adanya keinginan untuk tetap bersama dengan teman-temannya mendorong siswa untuk memilih program lintas minat yang sama. Hasil penelitian ini sejalan dengan temuan Suriyani (2016) yang menyatakan bahwa faktor teman sebaya merupakan salah satu faktor yang berpengaruh dalam pengambilan keputusan.

\section{SIMPULAN}

Hasil penelitian ini menunjukan bahwa variabel minat, motivasi, keluarga, guru dan teman sebaya secara simultan berpengaruh signifikan terhadap keputusan memilih program lintas minat ekonomi di SMA Negeri 4 Makassar, sedangkan secara parsial, beberapa faktor yang berpengaruh terhadap keputusan memilih program lintas minat ekonomi yaitu faktor minat, faktor guru dan faktor teman sebaya. Faktor motivasi dan faktor keluarga secara parsial berpengaruh tidak signifikan terhadap keputusan memilih program lintas minat ekonomi di SMA Negeri 4 Makassar. Berdasarkan hal tersebut maka direkomendasikan dalam memilih program lintas minat harus lebih mempertimbangkan pemahaman, kemampuan dan keyakinan diri terhadap pengambilan keputusan yang nantinya akan dipilih, sehingga keputusan dapat menunjang dalam pilihan karir siswa setalah tamat pada jenjang SMA.

Keluarga, guru, dan sekolah diharapkan ikut serta dalam memberikan pengarahan yang positif terhadap keputusan siswa dalam memilih program lintas minat ekonomi, karena dengan adanya dukungan dan dorongan dari 
beberapa pihak, maka siswa akan lebih mantap, percaya diri dan yakin dalam pengambilan keputusan bagi masa depannya.

\section{DAFTAR RUJUKAN}

Abarro, J.O. 2016. Factors Affecting Career Track and Strand Choices of Grade 9 Students in the Division of Antipolo and Rizal, Philippines. International Journal of Scientific and Research Publications 6(6): 5153.

Afriska, A.E. 2015. Pengaruh Minat dan Motivasi Siswa Terhadap Keputusan Memilih Program Lintas Minat Ekonomi SMAN 1 Binangun Kabupaten Cilacap. Skripsi. Universitas Negeri Semarang. Semarang.

Bandura, A. 1989. Human Agency in Social Cognitive Theory. American Psychologist 44(9): 1175-1184.

Devianti, R. 2015. Kontribusi Dukungan Orang tua, Teman Sebaya, dan Guru Bimbingan dan Konseling terhadap Minat Siswa pada Jurusan yang Ditempati di SMA. Jurnal Konseling dan Pendidikan 3(2): 22-30.

Dustmann, C., Puhani, P. and Schonberg, U. 2016, The Long-term Effects of Early Track Choice. Economic Journal 127(603): 1348-1380.

Guay, F., Senecal, C., Gauthier L., and Ferne, C. 2003. Predicting Career Indecision: A Self-Determination Theory Perspective. Journal of Counseling Psychology 50(2): 165-177.

Gujarati, D. N., and Dawn C.P. 2009. Basic Econometrics. The McGraw-Hill Companies Inc. Singapura.

Guyon, N., Maurin, E. and McNally, S. 2012. The Effect of Tracking Students by Ability into Different Schools: a Natural Experiment, Journal of Human Resources 47(3): 684-721.

Handoko, T.H. 2011. Manajemen Personalia dan Sumberdaya Manusia. Penerbit BPFE. Yogyakarta.

Istifarani, F. 2016. Pengaruh Dukungan Keluarga Terhadap Pengambilan Keputusan Karir Siswa Kelas X di SMK Negeri 1 Depok. Jurnal Bimbingan dan Konseling 4(1): 1-11.

Istiqomah, P. 2017. Faktor yang Mempengaruhi Minat Siswa dalam Pemilihan Mata Pelajaran Keterampilan Hidup Mandiri Tata Busana Kelas X di MAN Godean Yogyakarta. Skripsi. Universitas Negeri Yogyakarta. Yogyakarta.

Koech, J., Bitok, J., Rutto, D., Koech, S., Okoth, J.O., Korir, B., and Nngala, H. 2016. Factors Influencing Career Choices Among Undergraduate 
Students in Public Universities in Kenya: A Case Study of University of Eldoret. International Journal of Contemporary Applied Sciences 3(2): 50-63.

Lent, R.W., Brown, S.D., Hackett, G. 1994. Toward a Unifying Social Cognitive Theory of Career and Academic Interest, Choice, and Performance. Journal of Vocational Behavior 45(1): 79-122.

Mau, W.C. J., and Li, J. 2018. Factors Influencing STEM Career Aspirations of Underrepresented High School Students. Career Development Quarterly 66(3): 246-258.

Miller, K., Sonnert, G. and Sadler, P. 2018. The Influence of Students' Participation in STEM Competitions on Their Interest in STEM Careers. International Journal of Science Education, Part B: Communication and Public Engagement 8(2): 95-114.

Munarfah, A., dan Muhammad, H. 2009. Metode Penelitian. CV. Praktika Aksara Semesta. Jakarta.

NCES. Gender Differences in Science, Technology, Engineering, and Mathematics (STEM) Interest, Credits Earned, and NAEP Performance in the 12th Grade (NCES 2015-075). National Center for Education Statistics, Institute of Education Sciences, U.S. Department of Education. Washington, DC, USA.

Papalia, E.D. 2009. Human Development: Perkembangan Manusia. Salemba Humanika. Jakarta.

Pascual, N. 2014. Factors Affecting High School Students' Career Preference: A Basis for Career Planning Program. International Journal of Sciences: Basic and Applied Research 16(1): 1-14.

Patrick, L., Care, E. and Ainley, M. 2011. The Relationship Between Vocational Interests, Self-efficacy, and Achievement in the Prediction of Educational Pathways. Journal of Career Assessment 19(1): 61-74.

Pop-Eleches, C. and Urquiola, M. 2013. Going to a Better School: Effects and Behavioral Responses. American Economic Review 103(4): 1289-1324.

Puspitasari, A., dan Patrikha F.D. 2018. Analisis Faktor-Faktor Yang Mempengaruhi Keputusan Pemilihan Universitas Pada Siswa Kelas XII SMA Negeri 22 Surabaya. Jurnal Pendidikan Ekonomi, Manajemen, dan Keuangan 2(1): 1-10.

Rottinghaus, P.J., Falk, N.A., Park, C.J. 2018 Career Assessment and Counseling for STEM: A Critical Review. The Career Development Quarterly 66(1): 2-34. 
Rufaidah, A. 2015. Pengaruh Intelegensi dan Minat Siswa terhadap Putusan Pemilihan Jurusan. Faktor - Jurnal Ilmiah Kependidikan 2(2): 139-146.

Suriyani, K.W. 2016. Faktor-Faktor yang Mempengaruhi Keputusan Mahasiswa dalam Memilih Jurusan Akuntansi Program S1 di Universitas Pendidikan Ganesha. Ekuitas - Jurnal Pendidikan Ekonomi 4(2): 51-61.

Syafaruddin, A. 2004. Sistem Pengambilan Keputusan Pendidikan. Penerbit PT. Grasindo. Jakarta.

Toker, Y., and Ackerman, P. L. Utilizing Occupational Complexity Levels in Vocational Interest Assessments: Assessing Interests for STEM Areas. Journal of Vocational Behavior 80(2): 524-544.

Woolfolk, A. 2009. Educational Psychology: Active Learning. Pustaka Pelajar. Yogyakarta. 